\title{
TITLE:
}

\section{PLATYSYMPUS JAPONICUS SP. NOV., A NEW CUMACEAN CRUSTACEA FROM SAGAMI BAY}

\author{
$\operatorname{AUTHOR}(\mathrm{S}):$ \\ Gamo, Sigeo
}

\section{CITATION:}

Gamo, Sigeo. PLATYSYMPUS JAPONICUS SP. NOV., A NEW CUMACEAN CRUSTACEA FROM SAGAMI BAY. PUBLICATIONS OF THE SETO MARINE BIOLOGICAL LABORATORY 1975, 22(5): 229-235

\section{ISSUE DATE:}

1975-11-29

URL:

http://hdl.handle.net/2433/175904

RIGHT: 


\title{
PLATYSYMPUS JAPONICUS SP. NOV., A NEW GUMAGEAN CRUSTAGEA FROM SAGAMI BAY ${ }^{1 \text { ) }}$
}

\author{
Sigeo GAMÔ \\ Faculty of Education, Yokohama National University, Yokohama
}

With Text-figures $1-2$

In the Genus Platysympus (Family Lampropidae) there have been three species and one unidentified species. Platysympus typicus (G.O. Sars, 1870), P. tricarinatus Hansen, 1920 and P. sp. (Zimmer, 1940) have been restrictedly recorded within the waters of the northern Atlantic Ocean and the Mediterranean Sea; only P. brachyurus (Zimmer, 1907) has been described from the Antarctic region.

The new species to be described here is the first record of the genus from the Pacific Ocean. An adult female specimen was collected from off Shimoda, Sagami Bay by $R / V$ Tansei Maru of the Ocean Research Institute, University of Tokyo. The specimen was taken at maximum depth $480 \mathrm{~m}$ by oblique haul of ORI-net for macroplankton.

The author is grateful to Dr. Masaaki Murano of the Tokyo University of Fisheries who kindly sent him the specimen at his disposal for the study.

\section{Platysympus japonicus sp. nov.}

(Figs. 1, 2)

Description: The holotype is an adult female, length $7.8 \mathrm{~mm}$ (exclusive of the telson). The carapace is large, ellipsoidal in shape viewed from the dorsal side and the surface is much convex dorsally; the lateral aspect appears like a lenticular shape. The lateral border is furnished with a strong carina. On the dorsal surface the anterior half portion bears a dorso-median carina and the posterior half portion bears an elongate pear-shaped dorso-median depression, of which the posterior end is provided with a small salient dorso-median crest; the length of the depressed area is about two-fifths of the carapace length and three times the greatest width of the depression; the salient crest is as high as its width as measured at the base, and about one-half of its length which is about one-fifth of the carapace length. The pseudorostral lobes are very broadly, horizontally projected and bear a slight sinuation on each lateral side; they meet in front of the ocular lobe for a distance about two times as

1) This study was financed partly by a grant for the Scientific Research from the Ministry of Education, no. 84089 (in 1974).

Publ. Seto Mar. Biol. Lab., XXII (5), 229-235, $1975 . \quad$ (Article 15) 
long as the ocular lobe. The ocular lobe is very small, as long as wide and without discernible eyes. The length of the carapace is slightly more than two-fifths of the total length of the animal (exclusive of the telson) and nearly one and one-third times the width. The greatest width is seen across the middle portion of the carapace and about one and two-thirds times the depth.

The total of the free thoracic segments is two-fifths of the carapace length. The first segment is large, saddle-like shape, about one-fourth as long as the total length of the free thoracic segments and nearly as long as the second segment; its anterior end is abruptly expanded, much more than twice as high as and as wide as the length of the segment and bears narrow lateral plate; the posterior part of the segment is strongly narrowed and its diameter is about one-half of the anterior part. The third and fourth segments both are nearly subequal in length and each is about a half length of the second. The fifth segment is a little longer than the fourth. The second to fifth segments have about the same width and their lateral plates are rather small, fringed with spinules and hairs.

The abdomen is very slender and its length is a little less than one-half of the body length. The first to fifth segments are successively increased in length. The fifth segment is about twice as long as the first. The sixth segment is very short, about two-fifths as long as the fifth.

The antennule has three peduncular segments, each bears lamellae on the distal and lateral borders. The first peduncular segment is the longest, much longer than the two distal segments together. The second segment is a little shorter than twothirds of the first segment and nearly as long as one and a half times of the third segment. The main flagellum has three segments and is nearly one and one-fifth times as long as the accessory flagellum. The second segment has an aesthetascs and two short hairs on the distal margin. The third segment is one-third as long as the second and bears an aesthetascs and five hairs on the distal margin.

The antenna (Fig. 1, E) is rudimentary and has four segments; the distal segment bears lamellae on the lateral margin and three hairs on the distal end.

The mandible (Fig. 1, F) is normal shape of the genus. There are 13 setae on the right, and 12 setae and a lacinia mobilis on the left side mandible.

The first and second maxillae are normal type of the genus, the first maxilla has no palp.

The first maxilliped bears one accessory lobule and several branchial lobules.

The second maxilliped is shown in Fig. 2, B.

The basis of the third maxilliped is rather slender, not expanded distally, a little broader than the base of the ischium and a little stouter at the base; its length is measured slightly less than one and one-fourth of the distal segments together; there are several short plumose hairs on the distal inner border and three long plumose hairs on the external outer border. The ischium is very short. The merus is about a half length of the carpus and furnished with plumose hairs and lamellate spines. The inner border of the carpus bears lamellate spines and several plumose setae. The propodus is about one-half as long as the carpus and twice as long as the dactylus. 


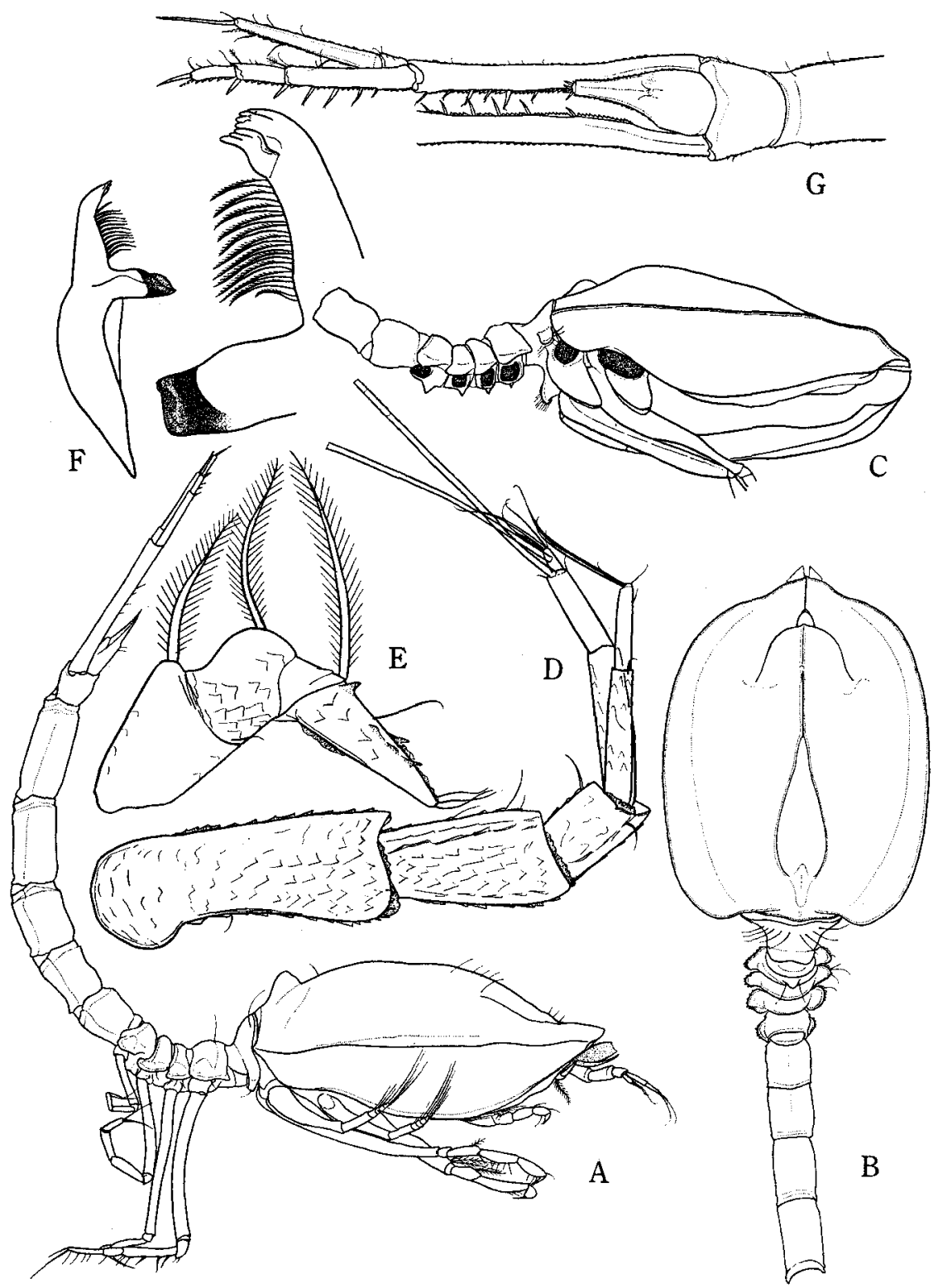

Fig. 1. Platysympus japonicus sp. nov., holotype adult female (length, $7.8 \mathrm{~mm}$, exclusive of telson). A: lateral view. B: anterior portion of body, from above. C: anterior portion of body, lateral view (right thoracic appendages are removed). D: antennule. E: antenna. F: right and left mandibles (left mandible is enlarged). G: posterior portion of abdomen, with uropod and telson. 
The basis of the first peraeopod is much longer than one and one-third times the length of the distal segments together; the distal portion is not expanded and furnished with four short plumose setae on the inner and five such setae on the outer border; there are lamellate serrations along the lateral borders. The ischium is extremely short. The merus is a little longer than one-half the length of the carpus and bears lamellate serrations with a distal plumose setae on the inner border, and a short spine and a plumose seta on the outer distal angle. The carpus is one and one-fourth times as long as the propodus and bears lamellate serrations with four plumose setae on the inner border; the external border is partly serrated. The inner border of the propodus bears lamellate serrations and a distal plumose seta. The dactylus is about one-half the length of the propodus and bears several setae on the lateral borders and at the apex.

The second peraeopod is very long and slender, a little shorter than the first peraeopod; the basis is about as long as the remaining distal segments together and bears lamellate serrations on the lateral borders. The ischium and merus are short. The carpus is longer than the propodus and dactylus combined. The dactylus is nearly one-third the length of the carpus and bears spines on the lateral borders and at the apex.

The third peraeopod is about three-fourths as long as the second; the basis is about one and one-half times the length of the distal segments combined and bears lamellate serrations on the lateral borders. The ischium is very short. The merus is slightly longer than the carpus which is subequal to the length of the propodus. The dactylus is very short, one-fourth as long as the propodus and bears two unequal setae at the apex.

The fourth peraeopod is six-sevenths as long as the third; the basis is a little shorter than the distal segments together. The ischium is very short. The merus, carpus and propodus are about subequal in length respectively. The dactylus is very short and furnished with two unequal setae on the distal end.

The fifth peraeopod is slightly longer than two-thirds as long as the fourth; the basis is two-thirds as long as the distal segments together. The ischium is very short. The carpus is about one and one-half times the length of the merus which is as long as the propodus. The dactylus is short and bears two unequal spines at the apex.

The peduncle of the uropod is three and one-half times as long as the last abdominal segment and twice as long as the telson; the inner border is serrate and bears six or seven spines. The exopod is a little more than three-fourths as long as the endopod and a little less than two-thirds as long as the peduncle. The exopod is two-segmented; the proximal segment is very short, whereas the distal segment is about five times the length of the proximal segment; their lateral borders are finely serrate and furnished with three setae on the inner and three fine hairs on the outer border; there are a fine hair and a stout spine at the apex. The endopod has three segments; the first segment is the longest, nearly one-half the length of the exopod, about one and one-third times the total length of the distal two segments; five spines are on the 


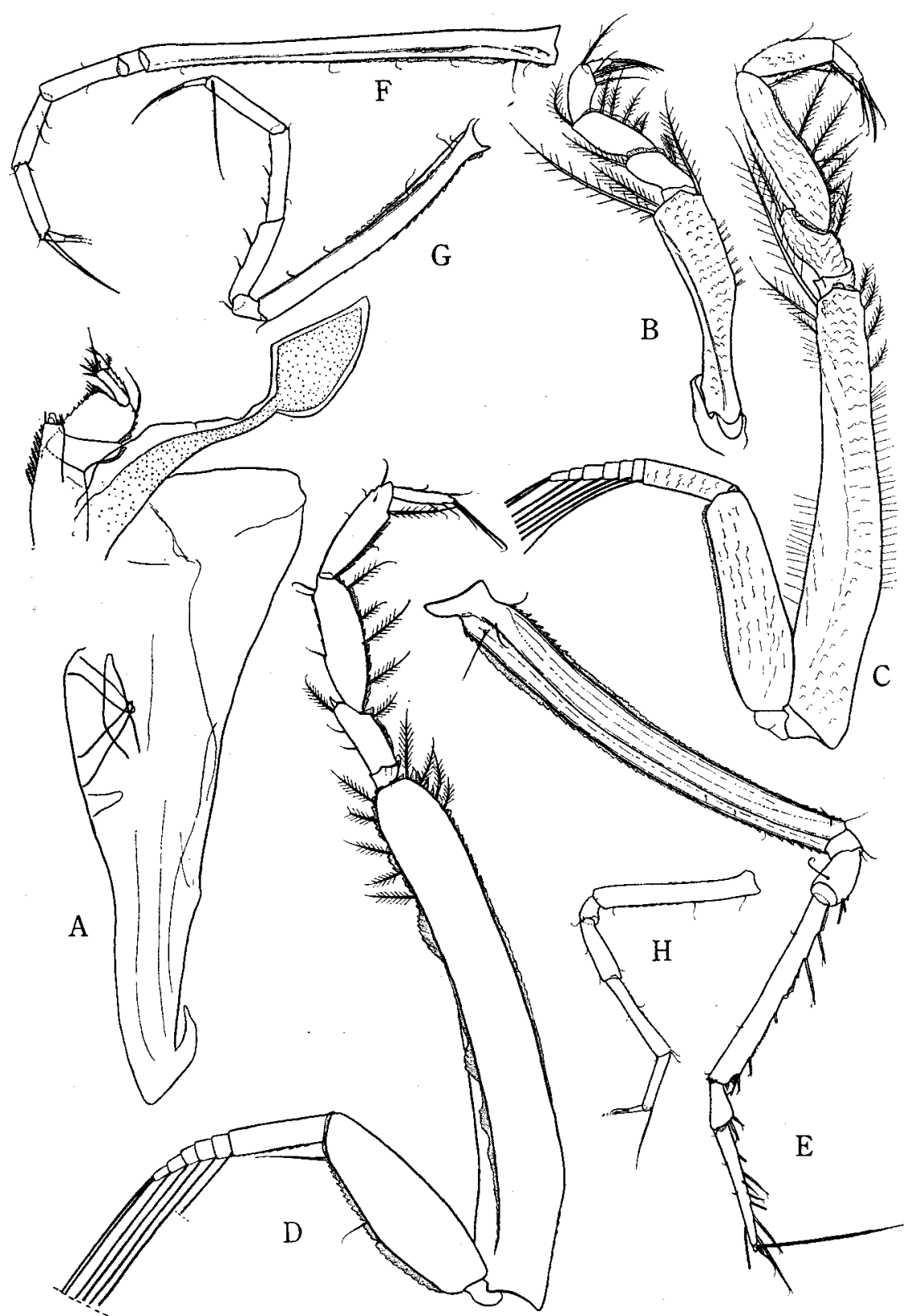

Fig. 2. Platysympus japonicus sp. nov., holotype adult female. A-C: first to third maxillipeds. D-H: first (D) to fifth (H) peraeopods. 
serrated inner border. The second segment is a little longer than the third and bears a distal spine on the serrated inner border. The third segment has fine serrations on the inner border and two unequal spines at the apex. The outer border of each endopodal segment has several fine hairs.

The telson is slightly less than twice as long as the last abdominal segment and one-half the length of the uropodal peduncle; the lateral borders are finely serrated and convex in their proximal part, while they are rather concave at about middle portion; there is a node-like tubercle with two short hairs in the middle of the dorsal surface; the distal end bears four unequal spines.

Material: 1 o adult (holotype), body length $7.8 \mathrm{~mm}$ (exclusive of telson). Off Shimoda in Sagami Bay, $34^{\circ} 44.8^{\prime} \mathrm{N}, 139^{\circ} 08.5^{\prime} \mathrm{E}$ (St. 202); taken at maximum depth $480 \mathrm{~m}$ by oblique haul of ORI-net (Ocean Research Institute-net for macroplankton), 18 October 1966 (Time: 14.49-15.21); collected by $R / V$ Tansei Maru of the Ocean Research Institute, University of Tokyo. The holotype will be deposited in the Ocean Research Institute.

Remarks: The new species is referred to the genus Platysympus Stebbing (1912) in the following points of characters: 1) the carapace is largely, horizontally expanded and strongly depressed dorso-ventrally and the abdomen is very slender, 2) the first maxilla without palp, 3) the distal border of the third maxilliped is not widened, only a little broader than the base of the ischium, 4) the first pair of peraeopods only bear the exopod in the female, 5) the fifth peraeopod is very little, but not rudimentary condition, and 6) the basis of the uropodal exopod is extremely short.

$P$. japonicus sp. nov. differs strongly from $P$. typicus (G.O. Sars) and P. brachyurus (Zimmer) in that 1) the general appearence of the carapace is different and the dorsal surface bears a short anterior carina and an elongate posterior depression with a hind crest which lies along the middle line; 2) the first free thoracic segment is strongly narrowed backward; 3 ) the distal end of the telson has four subequal spines, whereas the old two species have three apical spines on the telson.

By having the similar shape of the first free thoracic segment, the new species is very closely allied to $P$. tricarinatus Hansen, from which it can be distinguished easily by 1 and 3 of the above mentioned characters and also the carapace without three keels on the dorsal surface.

\section{LITERATURE}

Bacescu, M. 1972. Archaeocuma and Schizocuma, new genera of Cumacea from the american tropical waters. Rev. Roum. Biol., Zoologie. T. 17, pp. 241-250, 4 figs.

Fage, L. 1951. Les Cumacés. Faune de France. T. 54, pp. 1-136, 109 figs. Paul Lechevalier. Paris. Gamô, S. 1971. Rapport préliminaire sur quatre especes de Cumacés des eaux profondes du Japon. Zool. Mag., Tokyo. vol. 80, pp. 251-255, 2 figs.

Hansen, H.J. 1920. Crustacea Malacostraca. IV. Danish Ingolf Exped., vol. 3, pp. 1-86. Copenhagen. Jones, N.S. 1969. The systematics and distribution of Cumacea from depths exceeding 200 meters. Galathea Rep., vol. 10, pp. 99-180, 34 figs.

Lomakina, N.B. 1958. Cumacea of the Seas of U.S.S.R., pp. 1-310, 201 figs. U.S.S.R. Acad. Sci. Publ. House. Moscow and Leningrad. (In Russian). 
1968. Cumacea of the Antarctic region (after the materials of the Soviet Antarctic Expedition 1956-1958 and 1963). Researches of the Soviet Antarctic Expedition (1955-1958). 4, pp. 97-140. (In Russian).

Sars, G.O. 1899-1900. Cumacea. An account of the Grustacea of Norway, with short descriptions and figures of all the species. vol. 3, pp. $\mathrm{i}-\mathrm{x}, 1-114$. Bergen.

Stebbing, T.R.R. 1912. The Sympoda. Ann. S. Afr. Mus., vol. 10, pp. 129-176, 16 pls.

1913. Cumacea (Sympoda). Das Tierreich. Lief. 39, pp. i-xvi, 1-210, 137 figs. Berlin.

Zimmer, C. 1907. Neue Cumaceen von der Deutschen und der Schwedischen Südpolarexpedition aus den Familien der Cumiden, Vaunthompsoniiden, Nannastaciden und Lampropiden. Zool. Anz., Bd. 31, pp. 367-374.

1940. Die Verbreitung der Cumaceen. Arch. Naturg., (2) Bd. 9. pp. 224-313, 2 figs.

1941. Cumacea. In: Bronn's Klassen u. Ordnungen des Tierreich. Bd. 5, Abt. 1, pp. 1-222, 226 figs. Akad. Verlags. Leipzig. 